\title{
LIBYAN BIRDS. THE REMAINS OF THE ITALIAN ORNITHOLOGICAL COLLECTION IN THE ASSARAY AL-HAMRA MUSEUMS OF TRIPOLI, LIBYA
}

\begin{abstract}
This paper deals with the surviving ornithological stuffed specimens from the former Libyan Museum of Natural History, set up in Tripoli in 1936, in the extant Assaray Al-hamra Museums. The aim of this note is to provide a checklist of the stuffed birds still on display in the cases, while taking the opportunity to furnish a range of additional information that augments our knowledge of the current Libyan ornithofauna and also documenting its past diffusion in the north-African state. All the data recorded were gathered prior to the civil unrest that broke out in Libya in February 2011.
\end{abstract}

Key words - Libyan birds, Assaray Al-hamra Museums, Libyian Museum of Natural History of Tripoli, ornithological collections.

Riassunto - Uccelli libici. La collezione ornitologica italiana all'Assaray Al-hamra di Tripoli.

Il presente lavoro si occupa di quella parte della collezione ornitologica del Museo Libico di Storia Naturale di Tripoli, fondato nella capitale libica nel 1936, che è confluita nell'attuale Assaray Al-hamra. Scopo della nota è quello di redigere una checklist degli esemplari ancora esibiti nelle teche espositive, cogliendo l'occasione per fornire una serie di informazioni ulteriori che integrino la nostra conoscenza sulla passata diffusione della fauna ornitica nello stato nordafricano. Tutti i dati esposti sono stati raccolti prima dei disordini civili iniziati in Libia nel febbraio 2011.

Parole chiave - uccelli di Libia, Assaray Al-hamra, Museo Libico di Storia Naturale di Tripoli, collezioni ornitologiche.

\section{Introduction}

Prior to the Italian occupation of Libya, the local ornithofauna, which includes Palaearctic, Afrotropical and Oriental elements, was the subject of a very modest scientific research. In the early 20 th century, a small collection, composed of about sixty specific and subspecific taxa, had

Department of Biology of the University of Florence. Laboratories of Anthropology and Ethnology. Via del Proconsolo, 12 - I-50122 Florence. E-mail: marco.masseti@unifi.it 
been gathered by Edward Dodson on behalf of J.I.S. Whitaker (TREVELYAN, 1977; Lo VAlVO \& MASSA, 2000), who determined them scientifically and published their checklist (WHITAKer, 1902 and 1903). These were mostly migratory Palaearctic birds, wintering in central and southern Africa, that is Mediterranean species dispersed all over northern Africa and southwestern Asia, which, however, as a whole GHIGI (1913) did not hesitated to define as having no "faunistic value" at all. The creation of this early small collection was carried out before the war between Italy and Turkey in 1911 which, following the victory of Italy over the Ottoman Empire, led to Libya and the islands of the Dodecanese being comprised within its colonial boundary. After the end of the First World War, the Libyan avifauna became the subject of important studies carried out by several Italian zoologists, such as Ghigi (1913, 1920 and 1921) (Cirenaica), Salvadori \& Festa (1922), Scortecci (1934 and 1935) (Fezzan, Tassili), Zavattari (1934) (Cufra, Fezzan), Moltoni (1935), and Toschi (1941, 1969), in particular after the Italian occupation of the North-African country and also before the start of the collection of materials that led to the establishment of the ornithological collection of the Libyan Museum of Natural History (Museo Libico di Storia Naturale), set up in Tripoli in 1936 (Desio, 1939 and 1942). However, since Scortecci's visit to Fezzan in 1934, which produced records of 22 species, mostly migrants, no ornithologist appears to have returned prior to the visit of Guichard in 1952 and 1953 (Guichard, 1955). Part of the materials collected flowed into other Italian collections, among which we can recall that of Ettore Arrigoni degli Oddi currently housed in the Museo Civico di Zoologia of Rome (cf. Foschi et alii, 1996).

Based on the evaluation of the documents still available at the Assaray Al-hamra $\mathrm{Mu}$ seums, however, it is not possible to ascertain how much of this material was incorporated into the original collections of the Museo Libico di Storia Naturale of Tripoli (Fig. 1).

Moreover, in the course of recent decades, the study of

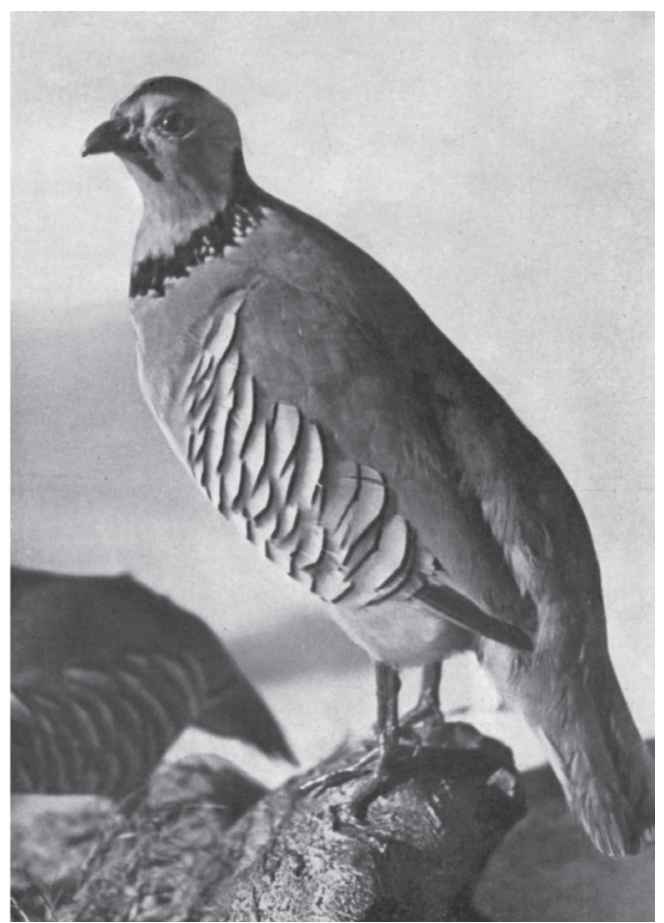

Fig. 1 - Stuffed Barbary partridge, Alectoris barbara (Bonaterre, 1792) (from Conò, 1940). 


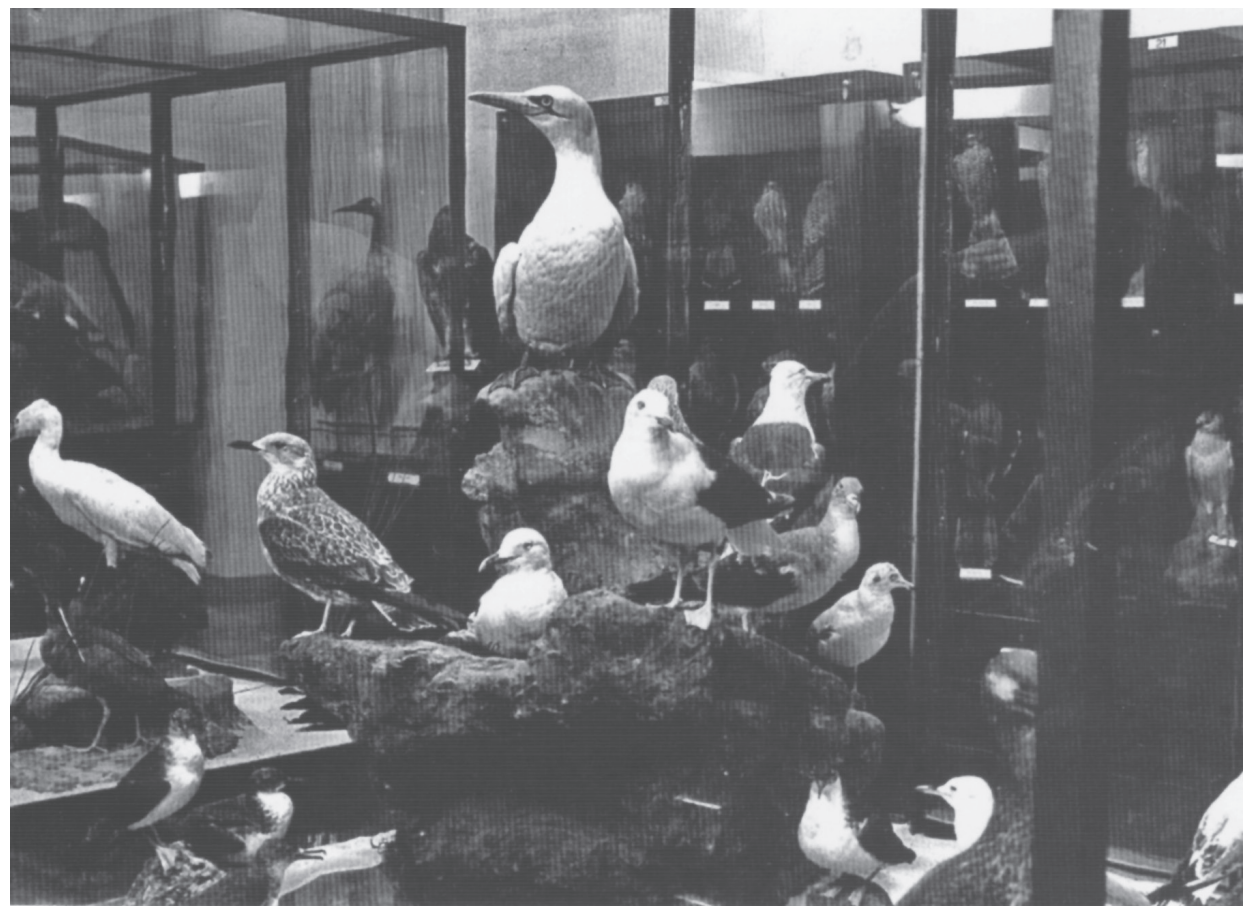

Fig. 2 - One of the cases from the former Museo Libico di Storia Naturale, set up in Tripoli in 1936. It is possible to recognise several stuffed specimens of seagulls, shearwaters, one gannet, Morus bassanus (L., 1758), one little egret, Egretta garzetta (L., 1766), and in the background one common crane, Grus grus (L., 1758), and perhaps a golden eagle, Aquila chrysaetos L., 1758. None of these birds are now on display in the Tripolitanian Assaray Al-hamra Museums (from GiUliano, 2009).

Libyan ornithofauna has been further penalised by the tangible impoverishment of the scientific material that originally made up the collections of the museum (Fig. 2). The latter have, in fact, been drastically reduced not only in relation to the reports on the same made during the Italian occupation of Libya (cf. CoRò, 1940), but even in relation to the information transmitted in much more recent times by some of the zoologists who found themselves working in the North-African state (cf. MASSETI, 2010). To cite just one mammalian example, of the three stuffed cheetahs, Acynonix jubatus (Schreber, 1776), exhibited in the museum at the beginning of the 1970s (cf. HufnaGL, 1972), only one is still on display. This specimen was prepared by the Italian taxidermist Giuseppe (Beppe) Giuliano (11st June 1911-4th December 1974), who worked in Tripoli from 1933 to 1970, the year in which the new Libyan government decided to repatriate all the Italians (Giuliano, 2009) (Fig. 3). He was the principal taxidermist involved in the creation of the Italian collections. 


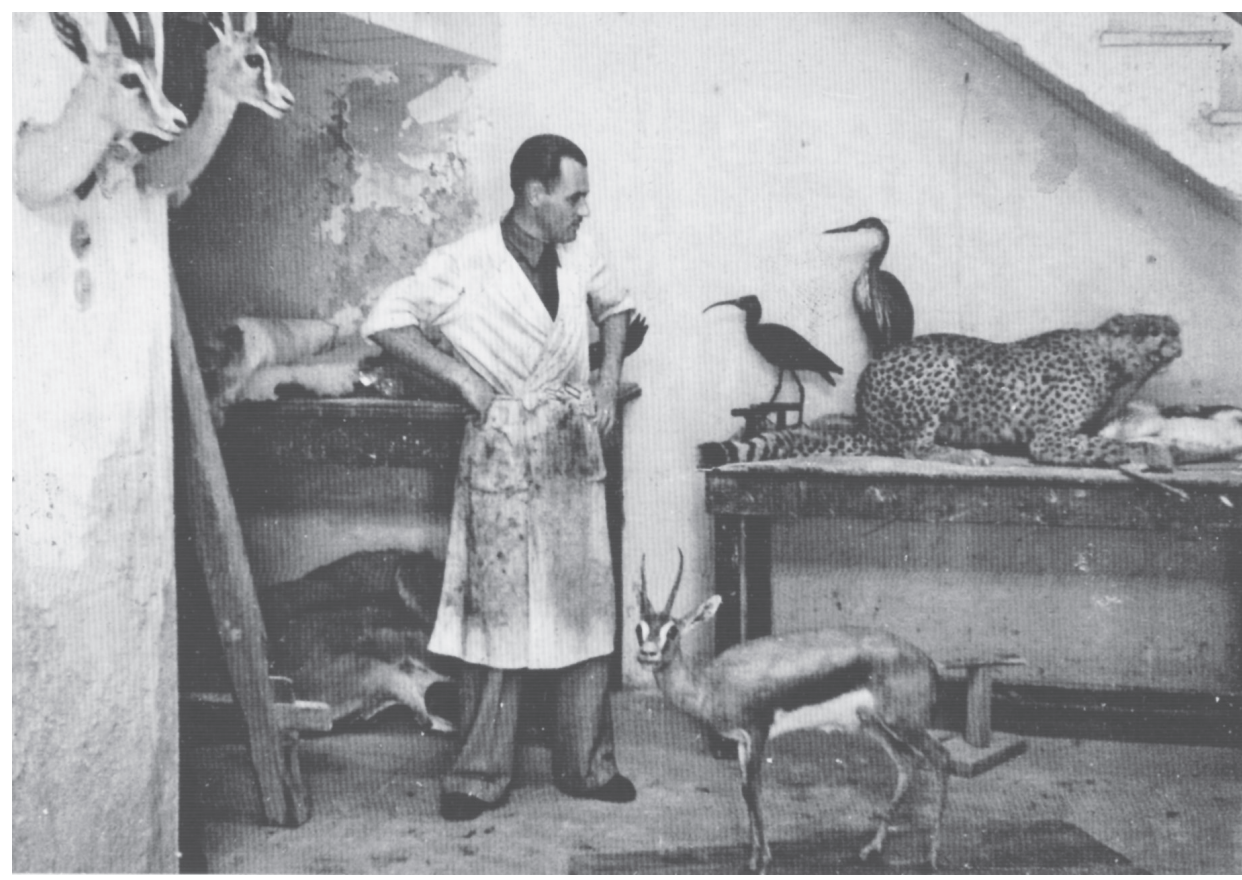

Fig. 3 - The laboratory of the Italian taxidermist Beppe Giuliano in Tripoli. It is possible to observe several naturalised animals; among them: one glossy ibis, Plegadis falcinellus (L., 1766), and one heron (from Giuliano, 2009).

The new layout of the museum of the castle of Tripoli, the Assaray Al-hamra Museums, has modified the space originally allocated to the Libyan Museum of Natural History, confining it to the fourth floor of the building, where the fauna (mammals, birds, reptiles and fossil specimens) is on display in rooms 40-46 (MASSETI, 2010). The aim of this paper is to give a checklist of the stuffed birds still on display in the cases of the museum, while also taking the opportunity to furnish a range of additional information that augments our knowledge of the current Libyan ornithofauna.

\section{Annotated checklist:}

The stuffed birds still on display are shown in several cases located at the entrance to the Natural History collections and in rooms 43 and 44.

\section{Entrance to the Natural History Section of the museum}

Case with one Golden eagle, Aquila chrysaetos L., 1758.

Case with one Long-legged buzzard, Buteo rufinus Cretzschmar, 1827, labelled as Buteo ferox Henderson \& Hume 1873. 
Buteo ferox is a synonym of $B$. rufinus, the scientific name of the Longlegged buzzard as used by MARToRelLi (1895). Moltoni (1935) regarded this bird of prey as a common resident in Tripolitania.

\section{Room 43}

Case with one Bonelli's eagle, Hieraaetus f. fasciatus Vieillot, 1822, seizing a red fox, Vulpes vulpes (L., 1758). The specimen was presented to the museum by Mrs. Al-Sherif, in 1956. According to MolToni (1935), this species was to be regarded as a common resident bird both in Tripolitania and Cyrenaica.

Case with one Short-toed eagle, Circaetus gallicus (Gmelin, 1788), obtained from Gharian, in 1952.

\section{Cases of Gallery 44}

One serin, Serinus serinus (L., 1766), labelled as Serinus canaria, from Tripoli, dated 1944.

The latter name was also adopted by Moltoni (1935) in the report of his ornithological excursion in Tripolitania, in April 1935. The Serin is described with the synomym of "Serinus canaries" in the original catalogues of Joseph Whitaker who collected - or had collected for him - several specimens in Morocco, Algeria and Tunisia, but not in Libya (see Lo VAlvo \& Massa, 2000). Moltoni (1935) regarded this species as a common resident in Tripoli and in some other oases not far from the sea, including the region of Gargaresch, in Zavia and Mellaha. The latter was an area where serins were particularly abundant.

One Collared pratincole, Glareola praticola (L., 1766), from Socna, dated 1928.

One Corn bunting, Emberiza calandra calandra L., 1758, from Tripoli, dated 1947.

One Hawfinch, Coccothraustes coccothraustes L., 1758, from Tajura (Tashura or Tagiura), a village originally $12-13 \mathrm{~km}$ east of Tripoli, today included within the periphery of the capital of Libya, dated 1927.

One Oyster catcher, Haematopus ostralegus L., 1758, from Tripoli, dated 1928, and labelled as Haematopus haematopus.

One Water rail, Rallus aquaticus L., 1758, from Tripoli, dated 1952.

One Woodcock, Scolopax rusticola (L., 1758), from Tajura (Tripoli), dated 1948. 
Moltoni (1935) reported the occurrence in Libya of this species for the first time, having been able to observe one individual in Homs, which had been killed in the region of Wadi Caàm. It was again MoLtoni (1935) who recorded the testimony of a much older capture of the species which took place in Wadi Rumia in 1913.

One Black-tailed godwit, Limosa limosa (L., 1758), from Tripoli, dated 1951.

One White pelican, Pelecanus onocrotalus (L., 1758), from Hun (around Seba), dated 1949 .

One Kentish plover, Charadrius alexandrinus L., 1758, from Tripoli, dated 1928.

According to Moltoni (1935), this species was to be regarded as a frequent winter visitor, and also a partial breeding-bird in Tripolitania.

One Great crested grebe, Podiceps cristatus (L., 1758), from Tripoli, dated 1949, and presented to the Museo Libico di Storia Naturale by Gian Giocondo Maraini.

One Shoveler, Anas clipeata L., 1758, from Tripoli, dated 1945, and presented to the Museo Libico di Storia Naturale by Gian Giocondo Maraini.

One Common teal, Anas crecca L., 1758, from Tripoli, dated 1940. It was presented to the Museo Libico di Storia Naturale by Gian Giocondo Maraini.

One Kingfisher, Alcedo attis attis (L., 1758), from Tripoli, dated 1937.

Two specimens of European roller, Coracias garrulus L., 1758, both from Garabulli, $30 \mathrm{~km}$ east of Tripoli, dated 1928.

One Fieldfare, Turdus pilaris L., 1758, from Tashara (Tajura?), 1945.

One juvenile of Egyptian vulture, Neophron pecnopterus (L., 1758), from the desert of Nalut, near Jeba, dated 1929. It was presented to the Museo Libico di Storia Naturale by Italo Balbo.

One Little owl, Athene noctua (Scopoli, 1769), from Tajura, dated 1926. Moltoni (1935) reputed it to be a common resident in Tripolitania. 1946.

One Scops owl, Otus scops (L., 1758), from Kars Ben Gashir, dated 
One Kestrel, Falco tinnunculus L., 1758, from Tripoli, dated 1937. According to Moltoni (1935), the species was both passage-migrant and common resident in Tripolitania.

One Eagle owl, Bubo bubo bubo (L., 1758), from Jadu, dated 1925.

One Great grey shrike, Lanius excubitur L., 1758, from Tripoli, dated 1948. Moltoni (1935) regarded this bird among common resident species in Tripolitania.

\section{Concluding remarks}

The stuffed birds still on display consist of only 27 specimens, belonging to 17 families (Podicipedidae, Pelecanidae, Anatidae, Accipitridae, Falconidae, Rallidae, Scolopacidae, Recurvirostridae, Charadridae, Glareolidae, Strigidae, Alcedinidae, Coracidae, Lanidae, Muscicapidae, Emberizidae, and Fringillidae), 25 genera, 26 species, of which 3 subspecies: Hieraaetus fasciatus fasciatus, Alcedo attis attis, and Bubo bubo bubo. They originated from about ten localities of Libya, mainly concentrated in the region of Tripolitania, its coast and the socalled Jebel, the upland desert region south of Tripoli (cf. MASsA, 1911; Petragnani, 1928), but also from more inland Saharan areas such as Socna (Sawknah) and Hun (Fig. 4). This collection is not of great value due to the lack of particularly rare or precious specimens. Its interest resides essentially in the fact that it is one of the rare historic collections of Libyan birds that has come down to us. It does, in fact, represent interesting documentation on the occurrence of birds species in the surroundings of Tripoli and, more in general, in Tripolitania between the end of the 1920s and of the 1940s. In Fig. 4 this information is compared to the geographic location of the sites of origin of the various specimens. The species represented are essentially Palaearctic taxa, more or less common to the rest of the Mediterranean shores. The data deriving from examination of the collection did not, in effect, document the diffusion of elements belonging to the Afrotropical zoogeography. According to the labels of the specimens still preserved in the cases, the collection was created between the years 1925 - date of the capture of the Eagle owl of Jadu - and 1965, when Mrs. Al-Sherif shot the Bonelli's eagle, although the principal acquisitions of the museum material were made between 1928 and 1948.

It could be interesting to note that the Common teal, the Shoveler, and Great crested grebe were presented to the museum by Gian Giocondo Maraini, known as Gianni (Savigliano, Cuneo 1905- Bussoleno, Val di Susa 1987), respectively in 1940, 1945, and 1949 (Fig. 5). All of them were 


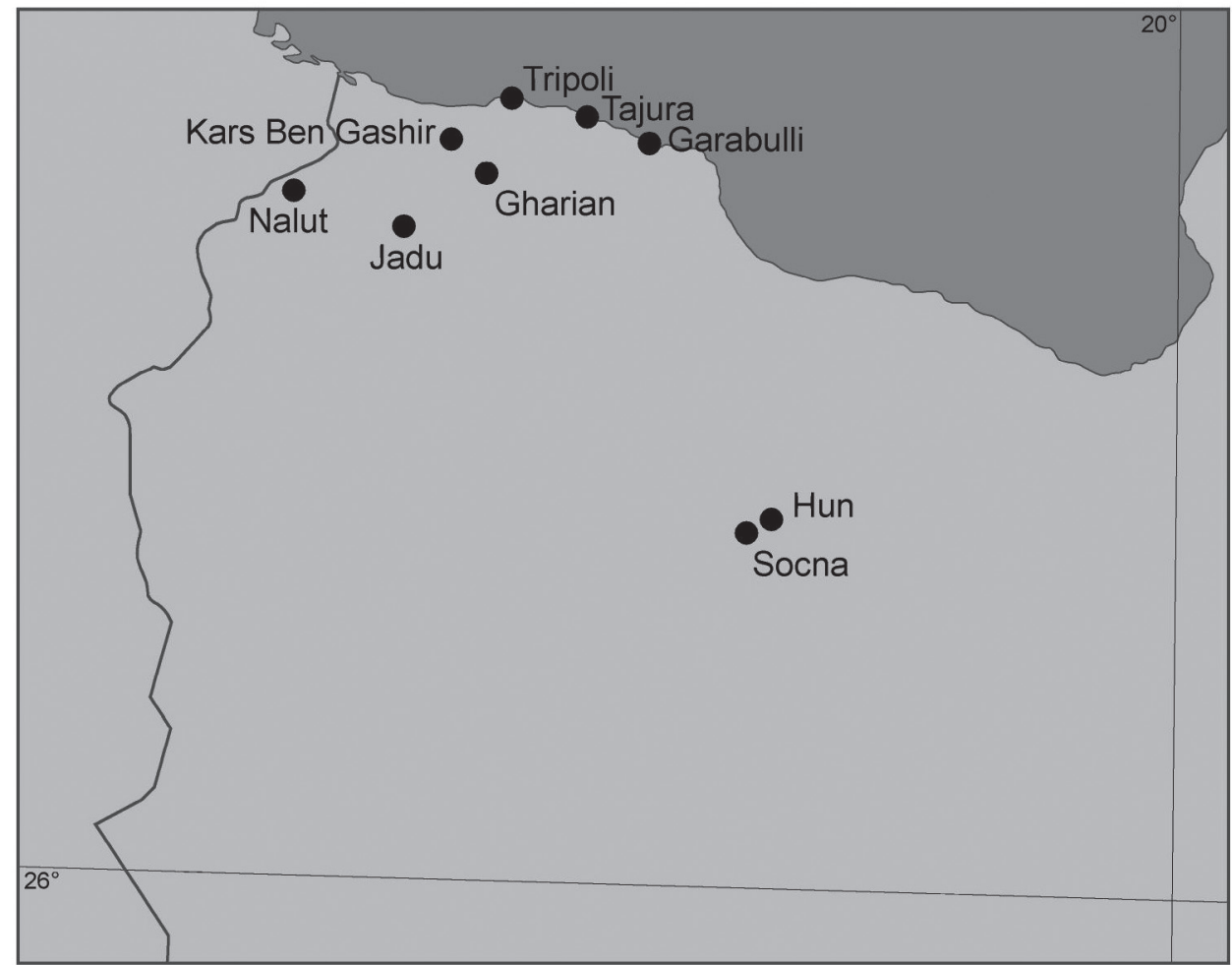

Fig. 4 - Geographical location of the sites of capture of the stuffed specimens still on display in the Assaray Al-hamra Museums of Tripoli.

captured in the surroundings of Tripoli. Maraini had moved to Libya in the early $1930 \mathrm{~s}$, immediately after graduating in medicine in Italy. He had two sons, Giovanni, nicknamed Giannetto, and Emilio. He was a keen hunter, mainly of water fowl, partridges and hares, and a very fine ornithologist (Fig. 6). The Libyan Maraini are of the same stock as the Florentine Maraini family, albeit the Lugano branch since Giovanni's grandfather had moved to Turin his own lifetime. In Tripoli, marsh hunting was carried out essentially in three or four sites situated close to the sea and close to the mouths of seasonal streams and wadies. The principal locations were Wadi Kam, not far from Leptis Magna, and the swamps of Tauorga, beyond Zliten, east of Homs. Gian Giocondo Maraini's son Giannetto recalls that the sites suitable for duck hunting closest to Tripoli also included Tajura (Tagiura, Tashura, Tahura), which is now a suburb of the latter, and Wadi Ramla, located respectively about 20 and $40 \mathrm{~km}$ east of the Libyan capital.

The Egyptian vulture from Nalut, a stretch of desert near Jeba, was instead killed by the general Italo Balbo, in 1929. He was the last governor 


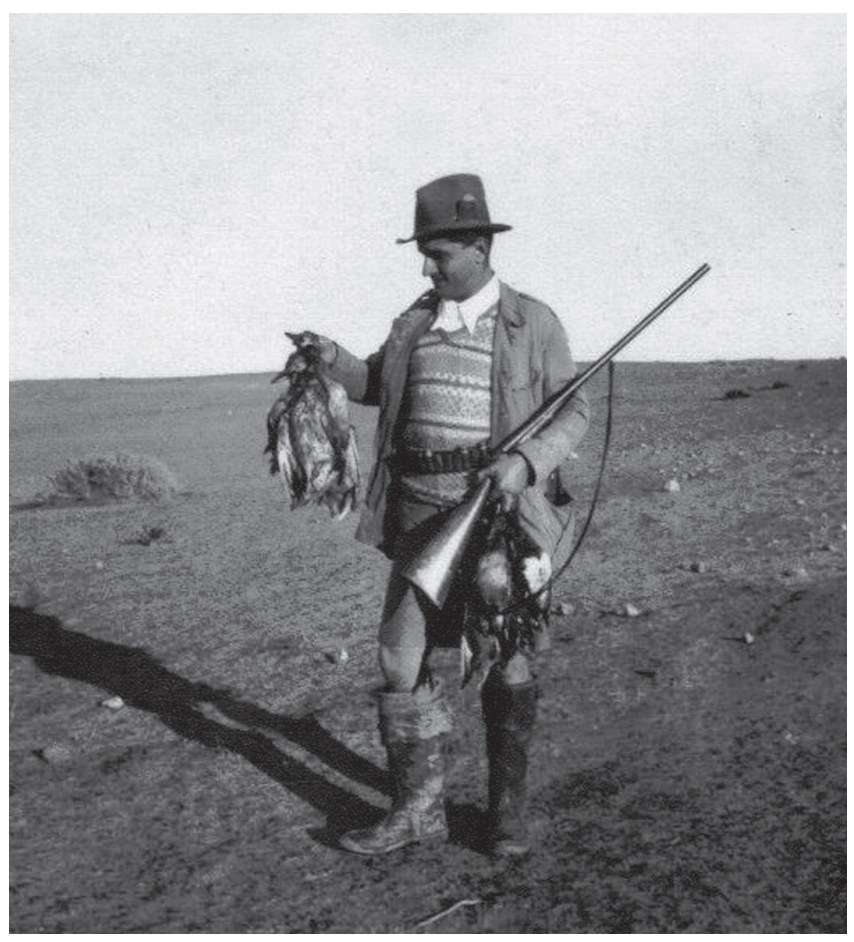

Fig. 5 - Gian Giocondo Maraini, a keen ornithologist, photographed during a hunting party at Wadi Kam (courtesy Giovanni Maraini).

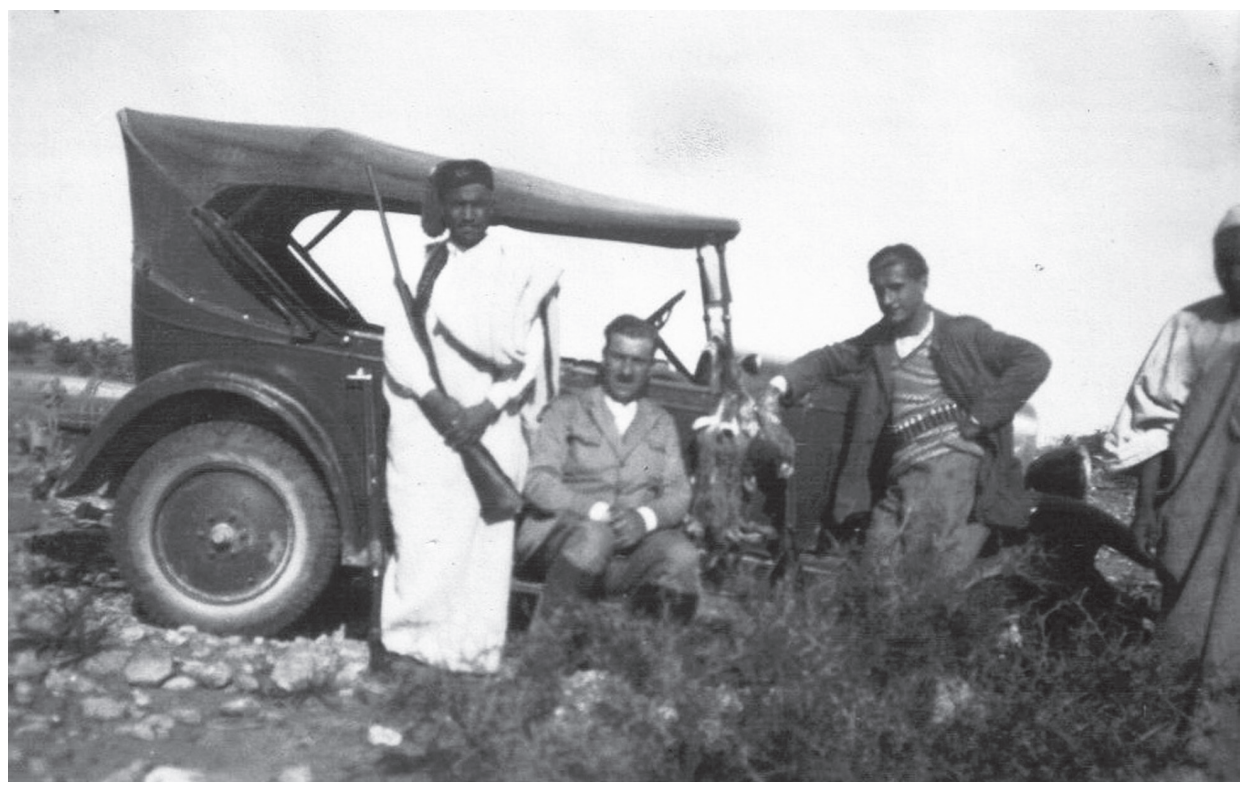

Fig. 6 - Barbary partridges and steppe hares in the game bag of Gian Giocondo Maraini (the second from right) (courtesy Giovanni Maraini). 
of the Italian colony of Libya, taking over from Pietro Badoglio in 1934, and remained in office up to 1940. In Italy Italo Balbo was a somewhat controversial figure, but he was extremely popular and adored in the former colony by the Italians, the Arabs and above all the Jews who, despite the racial laws in force in Rome, in Tripoli enjoyed total freedom and even benefited from not inconsiderable economic privileges (BARTOLI, 2004). His prowess as a hunter is undisputed, and his passion for hunting was common knowledge. Between 1937 and 1940, Balbo even managed to raise a cheetah to hunt bustards, hares and gazelles (HuFnaGL, 1972; Masseti, 2010). He was also one of the prime movers behind the summoning to Tripoli of the aforementioned taxidermist Beppe Giuliano (CORRIERE DI TRIPOLI, 1958). In Libya, the technical skill of the latter was: "... noted by the Governor Italo Balbo, a keen hunter, so much so that Beppe was called upon by the top executives of the museum (the Director Dr. Chiesa and Dr. Vergara) to deal personally with the preparation of the animals shot by the Italian general. This assignment meant that Beppe also took part in the general's hunting parties and it was thus that Italo Balbo, observing Beppe's expertise, began to take him with him everywhere he went, since the taxidermists had to follow the hunters so that they could begin work on the animal as soon as it was killed so as to prepare it for the following "naturalisation" (GIULIANo, 2009).

All the data presented in this work were collected prior to the civil unrest which broke out in Libya in February 2011.

Acknowledgements - While preparing this paper I have been fortunate in having had the help of many friends and colleagues. I am particularly grateful to Giovanni Maraini, Università di Parma; Maria Laura Trovato, Daniele Lombardi and Mauro Annese, Associazione Italiani Rimpatriati dalla Libia (AIRL), Roma; and Stefania Sani, Istituto Agronomico per l'Oltremare, Italian Ministry for Foreign Affairs (Firenze).

\section{REFERENCES}

Bartoli E., 2004 - Passato e presente. Gli italiani in Libia, quella fuga avventurosa - Corriere della Sera, 9th October 2004, p. 16.

Conò F., 1940 - La fauna grossa esistente in Libia. Alla caccia di antilopi e gazzelle, di lepri e otarde - Libia, 18: 9-14.

Corriere di Tripoli, 1958 - Il laboratorio del Museo di Storia Naturale. 10 ottobre 1956: 2.

Desio A., 1939 - Presentazione. Annali del Museo Libico di Storia Naturale, 1: 3-4.

Desio A., 1942 - Il Museo Libico di Storia Naturale nel suo quinto anno di vita - Annali del Museo Libico di Storia Naturale, 3: 5-7.

Foschi U.F., Bulgarini F., Cignini B., Lipperi M., Melletti M., Pizzari T. \& Visentin M., 1996 - Catalogo della collezione ornitologica "Arrigoni degli Oddi" del Museo Civico di Zoologia di Roma - Ricerche di biologia della selvaggina, 97: 1-311.

Ghigi A., 1913 - Materiali per lo studio della fauna libica - Memorie della R. Accademia delle Scienze dell'Istituto di Bologna, Classe di Scienze Fisiche - Sezione delle Scienze Naturali, Serie VI, Tomo X (1912-1913): 253-296.

Ghigi A., 1920 - Vertebrati di Cirenaica - Memorie della R. Accademia delle Scienze dell'Istituto di Bologna, Classe di Scienze Fisiche - Sezione delle Scienze Naturali, Serie VII, Tomo VII 
(1919-1920): 197-212.

Ghigi A., 1921 - Una escursione zoologica in Cirenaica - Le Vie d'Italia, 27 (3): 283-288.

GiUliano E., 2009 - Gli imbalsamatori. I Giuliano, un secolo di attività tassidermistica a Borgo San Dalmazzo - Primalpe - Comune di Borgo San Dalmazzo.

Guichard K.M., 1955 - The birds of Fezzan and Tibesti - Ibis, 97 (3): 393-424.

Hufnagl, E., 1972 - Libyan mammals - The Oleander Press, Harrow (England).

Lo VAlvo F. \& Massa B., 2000 - Catalogo della collezione ornitologica Joseph Whitaker (18501936) - Il Naturalista siciliano, 24, Suppl.: 3-145.

Martorelli G., 1895 - Monografia illustrata degli uccelli di rapina in Italia (1895). Riedizione a cura di Fausto Barbagli - Memorie della Società Italiana di Scienze Naturali e del Museo Civico di Storia Naturale di Milano, XXXI (II) (2002): 1-210.

MAssa E., 1911 - La nuova colonia italiana - Il Secolo XX, anno X, n. 11: 922-936.

Masseti M., 2010 - Holocene mammals of Libya: a biogeographical, historical and archaeozoological approach - Journal of Arid Environments, 74: 795-805.

Moltoni E., 1935 - Escursione Ornitologica in Tripolitania (11-23 Aprile 1935) - Riv. ital. Orn., $\mathrm{V}, 3: 127-176$.

Petragnani E. 1928 - Il Sahara tripolitano. Collezione di opere e di monografie a cura del Ministero delle Colonie, 3 - Sindacato Italiano Arti Grafiche, Roma.

SAlvadori T. \& Festa E., 1922 - Missione zoologica del Dott. E. Festa in Cirenaica: I. - Uccelli - Bollettino dei Musei di Zoologia ed Anatomia comparata della R. Università di Torino, 36 (738): 318-352.

Scortecci G., 1934 - Cenni sui risultati di una campagna di ricerche zoologiche nel Fezzan Natura. Rivista di Scienze Naturali, 25 (3): 93-103.

SCORTECCi G., 1935 - Relazione preliminare delle ricerche zoologiche eseguite nel Fezzàn per conto della Reale Società Geografica - Bollettino della R. Società Geografica Italiana, 4: 279-291.

Toschi A., 1941 - La fauna della Libia e le sue possibilità venatorie - Gli Annali dell'Africa Italiana, anno IV, Volume II: 593-603.

Toschi A., 1969 - Introduzione alla ornitologia della Libia. Ecologia e zoogeografia della ornitofauna libica - Supplemento alle Ricerche di zoologia applicata alla caccia, 6: 1-381.

Trevelyan R., 1977 - Principi sotto il vulcano. Storia e leggenda di una dinastia di gattopardi anglosiciliani dai Borboni a Mussolini - Rizzoli editore, Milano.

Whitaker J.I.S., 1902 - On a small Collection of Birds from Tripoli - Ibis, 2 (8): 643-656.

WhitAKer J.I.S., 1903 - Rare Species of Birds from Tripoli - Bulletin of the British Ornithologists' Club, 13: 15-17.

Zavattari E., 1934 - Missioni del Prof Edoardo Zavattari nel Sahara libico 1934. Uccelli - Atti Soc. Ital. Sci . nat., 74: 5-18. 